\title{
CHEMICAL COMPOSITION AND FUMIGANT EFFECT OF ESSENTIAL OIL OF Lippia sidoides Cham. AND MONOTERPENES AGAINST Tenebrio molitor (L.) (COLEOPTERA: TENEBRIONIDAE)
}

\author{
Composição química e efeito fumigante do óleo essencial de Lippia sidoides Cham. e \\ monoterpenos sobre Tenebrio molitor (L.) (Coleoptera: Tenebrionidae) \\ Rafaela Karin Lima ${ }^{1}$, Maria das Graças Cardoso ${ }^{2}$, Jair Campos Moraes ${ }^{3}$, \\ Stephan Malfitano Carvalho ${ }^{4}$, Vanessa Gregório Rodrigues ${ }^{5}$, Luiz Gustavo Lima Guimarães ${ }^{2}$
}

\begin{abstract}
The chemical composition of Lippia sidoides essential oils obtained by hydrodistillation was characterized and quantified by GC/MS and their insecticidal activity by fumigation test was assayed against Tenebrio molitor. Moreover, the toxicity of monoterpenes carvacrol, 1,8-cineol and thymol were also evaluated when applied alone or in binary (1:1) or tertiary $(1: 1: 1)$ mixture. The essential oil of $L$. sidoides has as major constituents carvacrol (31.68\%), $\rho$-cymene (19.58\%), 1,8-cineole $(9.26 \%)$ and $\gamma$-terpinene $(9.21 \%)$, from a 21 compounds identified, being $92.53 \%$ of total. Both compounds have insecticidal activity against $T$. molitor, being the degree of toxicity of carvacrol $>1,8$-cineole $>$ L. sidoides essential oil $>$ thymol, and its respectively $\mathrm{LC}_{50}$ at $24 \mathrm{~h}$ were $5.53 ; 5.71 ; 8.04$ and $14.71 \mu \mathrm{L} / \mathrm{L}$ air. When the different mixture of carvacrol, 1,8-cineole and thymol was assayed against $T$. molitor, the synergism among them was observed. For the mixture of carvacrol:1,8-cineole $\mathrm{LC}_{50}$ was $5.34 \mu \mathrm{L} / \mathrm{L}$ air; carvacrol:thymol $7.67 \mu \mathrm{L} / \mathrm{L}$ air; 1,8 -cineole:thymol $7.51 \mu \mathrm{L} / \mathrm{L}$ air and carvacrol:1,8-cineole:thymol $6.34 \mu \mathrm{L} / \mathrm{L}$ air. Mainly, the monoterpene thymol had a synergic effect, which increased the toxicity of carvacrol and 1,8-cineole, both in binary mixture like carvacrol:thymol and 1,8-cineole:thymol.
\end{abstract}

Index terms: “Alecrim pepper”, mealworm, natural compound, toxicity, synergism.

\section{RESUMO}

A composição química do óleo essencial de Lippia sidoides obtido por hidrodestilação foi caracterizada e quantificada por GC/MS, bem como sua atividade inseticida por teste de fumigação foi avaliada sobre Tenebrio molitor. Além disso, a toxicidade dos monoterpenos carvacrol, 1,8-cineol e timol, também foi avaliada quando esses compostos foram aplicados isoladamente, ou em misturas binárias (1:1), ou terciárias (1:1:1). O óleo essencial de L. sidoides tem como principais constituintes o carvacrol (31,68\%), $\rho$-cimeno (19,58\%), 1,8-cineol (9,26\%) e $\gamma$-terpineno (9,21\%), em 21 compostos identificados, sendo 92,53\% do total. Ambos os compostos possuem atividade inseticida contra T. molitor, seguindo a ordem de toxicidade: carvacrol >1,8-cineol > óleo essencial de L. sidoides > timol; sendo suas respectivas $\mathrm{CL}_{50}$ à $24 \mathrm{~h}$ de 5,$53 ; 5,71 ; 8,04 \mathrm{e} 14,71 \mu \mathrm{L} / \mathrm{L}$ ar. Quando as diferentes misturas de carvacrol, 1,8-cineol e timol foram avaliadas contra T. molitor, verificou-se o efeito sinérgico. Para a mistura de carvacrol:1,8-cineol a $\mathrm{CL}_{50}$ foi de 5,34 $\mu \mathrm{L} / \mathrm{L}$ ar; carvacrol:timol de 7,67 $\mu \mathrm{L} / \mathrm{L}$ ar; 1,8-cineol:timol de 7,51 $\mu \mathrm{L} / \mathrm{L}$ ar e carvacrol:1,8-cineol:timol de 6,34 $\mu \mathrm{L} / \mathrm{L}$ ar. Principalmente o monoterpeno timol teve efeito sinérgico, aumentando a toxicidade de carvacrol e 1,8-cineol quando em misturas binárias, tais como carvacrol:timol e 1,8-cineol:timol.

Termos para indexação: Alecrim pimenta, bicho-da-farinha, produto natural, toxicidade, sinergismo.

(Received in february 2, 2011 and approved in march 1, 2011)

\section{INTRODUCTION}

During the storage of food, several problems can occur due the presence of insects such as the mealworm Tenebrio molitor (L.) (Coleoptera:Tenebrionidae). Their presence in stored grains and bran (i.e. corn, oat and wheat), can contaminate those food with fragments of his body, feces and indirectly by saprophytic microorganism, resulting in loss of quality (GARCIA et al., 2003; PINTO JUNIOR, 2008). Control of these insects can be achieved by methyl bromide and phosphine treatment; however, several issues have been discussed in the employment of insecticides, such as residue, environment impact and toxicity to humans (GHINI et al., 2002; LEE et al., 2004).

\footnotetext{
${ }^{1}$ Universidade Federal de São João Del-Rei/UFSJ - Departamento de Ciências Naturais - São João Del-Rei, MG 2Universidade Federal de Lavras/UFLA - Departamento de Química/DQI - Lavras, MG

3Universidade Federal de Lavras/UFLA - Departamento de Entomologia/DEN - Lavras, MG

"Universidade Estadual Paulista "Júlio de Mesquita Filho"/UNESP - Instituto de Biociências de Rio Claro - Centro de Estudos de Insetos Sociais Avenida 24A - 1515 - Bela Vista - 13506-900 - Rio Claro, SP - smalfitano@uol.com.br

${ }^{5}$ Universidade Federal de Minas Gerais/UFMG - Departamento de Química - Belo Horizonte, MG
} 
Therefore, one has sought for alternative defensives than showed a low impact in environment, and safe for human health, for example, natural extracts and secondary compounds derived from plants, which may be an important source of study in the pest control and simultaneously acting on the Integrated Pest Management (ISMAN, 2000). In this context, the species Lippia sidoides Cham. (Verbenaceae) which is popularly known as "alecrim" pepper, is a widespread plant in the northeast Brazil and showed a series of biological activities (CARTAXO et al., 2010). Their leaves have been used in alternative medicine to prevent acne, wounds, skin and scalp infections; and infusions are used for the treatment of rhinitis, vaginal diseases, mouth and throat infections (MENDES et al., 2010).

The essential oil of this species is rich in thymol and carvacrol, compounds that confer antimicrobial activity against fungi and bacteria, and they are also toxic to insects and spider mite (CAVALCANTI et al., 2004, 2010). According to Matos (2002), its leaves can present up to $4.5 \%$ of essential oils, with compounds such as thymol, carvacrol, 1,8-cineole, $\rho$-cymene, 4-terpineol, thymol methyl ether, transcariophyllene. The phytochemical extracts of leaves resulted in isolation of several other constituents, as oleanolic acid acetate, methyl-3,4-dihydroxibenzoate, lapachenol, tecomaquinone I, tectoquinone, tectol, acetylated tectol, quercetine, luteoline, glucoluteoline, lipisidoquinone, taxifolin and isolariciresinol (COSTA et al., 2002).

In this perspective, recent studies have reported a series of biological properties of essential oil, such as insecticidal activity on larvae of Aedes aegypti L. (CAVALCANTI et al., 2004); acaricidal activity aginst Tetranychus urticae (CAVALCANTI et al., 2010) bactericidal effect against Staphylococcus aureus, Pseudomonas aeruginosa and Escherichia coli (BERTINI et al., 2005; OLIVEIRA et al., 2006); Streptococcus spp. and Candida albicans (BOTELHO et al., 2007). Essential oils as well as several terpenes have been utilized in agriculture against fungi, bacteria, nematodes and pest insects. For example, the compounds thymol and 1,8cineole are already part of some commercial formulations (REGNAULT-ROGER, 1997; ISMAN, 2006).

Due the importance to know new strategies and alternatives for insect control, and the need in find new compounds with biological activity, the aim of this research was assess the chemical composition of essential oil of $L$. sidoides as well as their toxicity against the mealworm T. molitor. Moreover, the toxicity of carvacrol, 1,8-cineol and thymol was assayed alone or in mixture against this mealworm.

\section{MATERIAL AND METHODS}

\section{Essential oil extraction}

The fresh leaves of Lippia sidoides Cham. (Verbenaceae) were collected between the months of January and March over the morning period (between 8 and $9 \mathrm{~h}$ ) at the Medicinal Plants Garden, Federal University of Lavras ( $21^{\circ} 14^{\prime} \mathrm{S} ; 45^{\circ} 00^{\prime} \mathrm{W}, 919 \mathrm{~m}$ of altitude and annual average temperature of $26^{\circ} \mathrm{C}$ ). One vegetable sample was sent, processed and identified in the Biology Department of the Federal University of Lavras, being the voucher specimen deposited in the ESAL Herbarium (\# 01943). The sample employed in essential oil extraction was transported in identified plastic bag to the laboratory just after collection and then performed the hydrodistillation process using a modified Clevenger apparatus, with $300 \mathrm{~g}$ of leaves in $1 \mathrm{~L}$ of water during 2.5 hours. The hydrolate collected (aqueous and organic phases) were separated by centrifugation at $900 \mathrm{~g}$ for 5 minutes and the essential oil obtained was weighted, kept in amber flask wrapped with aluminum foil and stored under refrigeration at $4^{\circ} \mathrm{C}$ until their use.

\section{Identification and quantification of constituents}

The compounds were identified using a Shimadzu gas chromatography/mass spectrometry (GC-17A), with a selective mass detector (QP 5000). The equipment was operated with a fused silica capillary column with bonded phase (model DB5, $30 \mathrm{~m} \times 0.25 \mathrm{~mm}$ ) and helium as the carrier gas $(1 \mathrm{~mL} / \mathrm{min})$. The temperatures were of $220^{\circ} \mathrm{C}$ in the injector and $240^{\circ} \mathrm{C}$ in the detector. The oven temperature was scheduled for 40 to $240^{\circ} \mathrm{C}$, with additions of $3^{\circ} \mathrm{C}$ every minute. The compounds identification was performed by comparison the mass spectra with those in spectra library (Wiley 229) and the Kovats retention index (ADAMS, 2007). The quantification of constituents was performed in Shimadzu gas chromatograph (GC-17A) equipped with flame ionization detector and a fused silica capillary column with bonded phase (DB5, $30 \mathrm{~m} \times 0.25 \mathrm{~mm}$ ). The carrier was nitrogen at the rate $2.2 \mathrm{~mL} / \mathrm{min}$; the split rate 1:10 and injected volume of $1 \mu \mathrm{L}$. Initial temperature of the column was scheduled for 45 to $240^{\circ} \mathrm{C}$, with increases of $3^{\circ} \mathrm{C}$ each minute. Temperatures in injector and detector were set at 220 and $240^{\circ} \mathrm{C}$, respectively, and the column pressure at $115 \mathrm{KPa}$.

\section{Toxicological assay}

The fumigant effect of essential oil of $L$. sidoides and the monoterpenes carvacrol, 1,8-cineole and thymol (analytical grade, from Sigma Adrich, Milan, Italy) were carried out with unsexed adult of T. molitor, aged from two to five days. This insect was rearing with wheat/oat/corn 
bran (1:1:1), and maintained in wooden box $(70 \mathrm{~cm} \mathrm{x} 40 \mathrm{~cm}$ x $20 \mathrm{~cm}$ ) in darkness, at $25 \pm 2^{\circ} \mathrm{C}$ and $\mathrm{RH}$ of $60 \pm 10 \%$.

The first step of dose-response assays were performed with various concentrations $(\mathrm{v} / \mathrm{v})$ of the compounds administered alone. At the second step, to evaluate the synergism among few compounds from the essential oil, different mixture of monoterpenes carvacrol, 1,8 -cineole and thymol were prepared in the same proportion in binary mixture (1:1): carvacrol:1,8-cineole, carvacrol:thymol; and 1,8-cineole:thymol, as well as the tertiary mixture $(1: 1: 1)$ carvacrol:1,8-cineole:thymol. All solutions were prepared with acetone.

For the intoxication, $500 \mu \mathrm{L}$ of each solution was applied in $2 \mathrm{~cm}^{2}$ filter paper that was fixed into glass flask $(180 \mathrm{~mL})$. At the same time, each flask received six T. molitor adults and was immediately closed with plastic lid. For feeding insects, we used $200 \mathrm{mg}$ of the same diet describe above (SAHAF et al., 2007). During the assay, all glass flasks were maintained at the same climatic conditions where the insect were reared, and the number of dead beetle was recorded at 24 and $48 \mathrm{~h}$.

\section{Data analysis}

The data of dead insect recorded at 24 and 48 hours after the exposure to the different treatment, was submitted to a statistical analysis using the log-logistic model available in the "drc" package (RITZ; STREIBIG, 2005) and compiled by the statistical software $\mathrm{R}^{\circledR}$ (R DEVELOPMENT CORE TEAM, 2010). The lethal concentration which causes death of 50 and $90 \%\left(\mathrm{LC}_{50}\right.$ and $\mathrm{LC}_{90}$ ) of insects were determined (given in $\mu \mathrm{L}$ of compound/L air), as well as their confidence limits at $95 \%$.

To determine the effect of different mixture among carvacrol, 1,8-cineole and thymol, which can have a synergistic, antagonistic or neutral effect, we adopt the model of Metcalf (1967) to estimate the synergistic ratio (SR), but with modification, as follows:

average of $\mathrm{LC}_{50}$ of each compound alone

$$
\mathrm{LC}_{50} \text { of their mixture }
$$

Following this model when the SR value is 1, the toxicity of a mixture and their compounds isolated was equal; for values exceeding 1, synergism between compounds occurs; and for lower values than 1, the mixture of compounds showed an antagonism.

\section{RESULTS AND DISCUSSION}

\section{Chemical constitution of essential oil}

All compounds found in the essential oil of L. sidoides, its contents and Kovats index are shown in
Table 1. The hydrodistillation process used to prepare the essential oil of $L$. sidoides resulted in a transparent and slightly yellowish oil, with yield of $1.8 \%$ (w/w). The total of 21 compounds was identified, which correspond to $92.53 \%$. Only $7.47 \%$ of compounds were not identified by GC-MS process. The major constituents of this oil were carvacrol (31.68\%), $\rho$-cymene (19.58\%), 1,8-cineole $(9.26 \%), \gamma$-terpinene $(9.21 \%)$ and sabinene $(5.26 \%)$. In minor quantities, we found thymol-methyl-ether $(2.92 \%)$, thymol $(2.30 \%)$ and myrcene $(1.97 \%)$ among others. Below the rate of $1.90 \%$, several others compounds were found, gonna of $1.89 \%$ for thymol acetate at $0.09 \%$ for $\alpha$-humulene (Table 1 ).

The differences found in this study, when compared to some others in literature, may be explained by the edaphoclimatic effects as well as the analytical procedures employed. For example, Cavalcanti et al. $(2004,2010)$ found thymol as major compound in L. sidoides essential oils. However, only the first authors not found the presence of carvacrol. Following Botelho et al. (2007), who studied the microbial activity of the same essential oil, they found that the major constituents among others were thymol $(56.70 \%)$ and carvacrol $(16.70 \%)$, wich diverges with the results reported in this research, mainly the percentage of content.

For example, the difference in composition of essential oil of $L$. sidoides was described by Sousa et al. (2002) as a variation according to the extraction method, that may be performed by pressurized carbon dioxide or pressurized fluids (steam or ethanol). By the method employed, alterations in concentrations as well as in quantification can occur. Therefore, these differences justify the objective of developing research specific to the species found in one locality and not to generalize data from one location to another.

\section{Toxicological assay}

At high doses of essential oil of L. sidoides, carvacrol, 1,8-cineole and thymol, we verified greater mortality in adults of $T$. molitor (Table 2). According to data reported in Table 2 at 24 hours, carvacrol and 1,8-cineole showed largest toxicity, with $\mathrm{LC}_{50}$ of 5.53 and $5.71 \mu \mathrm{L} / \mathrm{L}$ air, respectively. The lethal concentration $\left(\mathrm{LC}_{50}\right)$ of the essential oil of $L$. sidoides against $T$. molitor was $8.04 \mu \mathrm{L} / \mathrm{L}$ air and for thymol $14.71 \mu \mathrm{L} / \mathrm{L}$ air. Similar behavior was observed in all $\mathrm{LC}_{50}$ values at 48 hours. An exception occurred when T. molitor was poisoned with 1,8-cineole and carvacrol at 48 hours. The lowest $\mathrm{LC}_{50}$ average was carvacrol $(4.77 \mu \mathrm{L} / \mathrm{L}$ air) followed by 1,8-cineole (5.27 $\mu \mathrm{L} / \mathrm{L}$ air), however for $\mathrm{LC}_{90}$, the more toxic was 1,8 -cineole with average of $6.83 \mu \mathrm{L} / \mathrm{L}$ air and not carvacrol (7.23 $\mu \mathrm{L} / \mathrm{L}$ air) (Table 2$)$. In general and timeindependent, the range of toxicity against $T$. molitor was carvacrol $>$ 1,8-cineole $>$ L. sidoides essential oil $>$ thymol. 
Table 1 - Chemical composition, Kovats index and percentage of compounds of the essential oil of Lippia sidoides.

\begin{tabular}{|c|c|c|}
\hline Compound & $\begin{array}{c}\text { Kovats retention } \\
\text { index }\end{array}$ & Content $(\%)$ \\
\hline$\alpha$-humulene & 1455 & 0.09 \\
\hline$\beta$-selinene & 1488 & 0.14 \\
\hline$\delta$-terpineole & 1170 & 0.15 \\
\hline Terpinolene & 1084 & 0.18 \\
\hline$\alpha$-terpineol & 1195 & 0.19 \\
\hline 1-octen-3-ol & 976 & 0.38 \\
\hline$\alpha$-thujene & 927 & 0.66 \\
\hline caryophyllene oxide & 1582 & 1.00 \\
\hline$\alpha$-phelandrene & 1006 & 1.28 \\
\hline 4-terpineol & 1181 & 1.39 \\
\hline$\alpha$-terpinene & 1016 & 1.50 \\
\hline (E)-caryophyllene & 1419 & 1.50 \\
\hline thymol acetate & 1364 & 1.89 \\
\hline Myrcene & 987 & 1.97 \\
\hline Thymol & 1290 & 2.30 \\
\hline thymol-methyl-ether & 1229 & 2.92 \\
\hline Sabinene & 968 & 5.26 \\
\hline$\gamma$-terpinene & 1058 & 9.21 \\
\hline 1,8-cineole & 1033 & 9.26 \\
\hline$\rho$-cymene & 1025 & 19.58 \\
\hline Carvacrol & 1302 & 31.68 \\
\hline \multicolumn{2}{|c|}{ Total identified } & 92.53 \\
\hline \multicolumn{2}{|c|}{ Total unidentified } & 7.74 \\
\hline
\end{tabular}

As the use of pure compounds (i.e. carvacrol, 1,8cineole and thymol) for pest control is expansive, the result obtained with the essential oils of $L$. sidoides showed that it can be used like a powerful insecticide. As the essential oil is a complex mixture, where the different compounds are in suffering some kind of interaction among them, we can affirm in this case that occur a synergism, which play an important role in insect toxicity.

The Table 3 shows the importance of interaction among the compounds existent in a complex mixture of essential oils, which is directly related to toxicity to insects. In all situations, the different mixture (binary and tertiary) of carvacrol, 1,8-cineole and thymol has a similar behavior concerning the toxicity against $T$. molitor, and in most cases they showed a short value of lethal concentration, when applied alone compared (Table 3 ). In this experiment, the lowest value was observed in carvacrol:1,8-cineole mixture with $\mathrm{LC}_{50}$ average at 24 hours of $5.34 \mu \mathrm{L} / \mathrm{L}$ air, followed by tertiary mixture of carvacrol:1,8-cineole:thymol $(6.34 \mu \mathrm{L} / \mathrm{L}$ air); thymol:1,8-cineole (7.51 $\mu \mathrm{L} / \mathrm{L}$ air) and carvacrol:thymol (7.67 $\mu \mathrm{L} / \mathrm{L}$ air). For 48 hours, we found the same behavior of toxicity that was found in 24 hours.

An important characteristic is the potentiation of certain compounds when mixed, commonly known as synergism. In this case, only the mixture of carvacrol:1.8cineole at 48 hours have a antagonistic effect compared when are applied alone, with SR of 0.97; where the others were strengthened at different ratio (Table 3). The short effect of synergism was observed when applied a binary mixture of carvacrol:1,8-cineole, that has a SR average of 1.05 , being most advantageous the use of isolate compound in detriment a mixture. For the tertiary mixture, we observed a average of SR of 1.23, being than the best

Table 2 - Lethal concentration (24/48 hours; $\mu \mathrm{L}$ essential oil /L air) in fumigation test of the chemical standards and the essential oil of Lippia sidoides to adults of Tenebrio molitor.

\begin{tabular}{|c|c|c|c|c|c|c|}
\hline \multirow{3}{*}{ Treatments } & \multicolumn{6}{|c|}{ Parameters } \\
\hline & \multicolumn{2}{|c|}{24 hours } & \multicolumn{2}{|c|}{48 hours } & \multirow{2}{*}{ D.F. } & \multirow{2}{*}{$\chi^{2}$} \\
\hline & $\mathrm{LC}_{50(\mathrm{CI} 95 \%)}$ & $\mathrm{LC}_{90(\mathrm{CI} 95 \%)}$ & $\mathrm{LC}_{50(\mathrm{CI} 95 \%)}$ & $\mathrm{LC}_{90(\mathrm{CI} 95 \%)}$ & & \\
\hline L. sidoides & $8.04_{(7.52-8.60)}$ & $12.47(11.06-14.07)$ & $7.04_{(6.58-7.53)}$ & $10.56(9.50-11.73)$ & 80 & 75.63 \\
\hline carvacrol & $5.53(5.21-5.87)$ & $8.78(7.83-9.84)$ & $4.77(4.48-5.08)$ & $7.23(6.58-7.94)$ & 92 & 65.38 \\
\hline 1,8-cineole & $5.71_{(5.33-6.12)}$ & $7.79(7.12-8.52)$ & $5.27(4.88-5.70)$ & $6.83(6.28-7.43)$ & 102 & 72.62 \\
\hline thymol & $14.71_{(13.77-15.71)}$ & $17.21_{(16.09-18.42)}$ & $12.69(11.05-14.58)$ & $16.77(15.17-18.55)$ & 90 & 80.03 \\
\hline
\end{tabular}

$\mathrm{LC}_{50}$ or $\mathrm{LC}_{90(\mathrm{Cl} 95 \%)}$ - lethal concentration and confidence limits at $95 \%$.

D.F. - degrees of freedom. $\chi^{2}-$ Chi-square value. $\quad \mathrm{N}=288$ insects. 


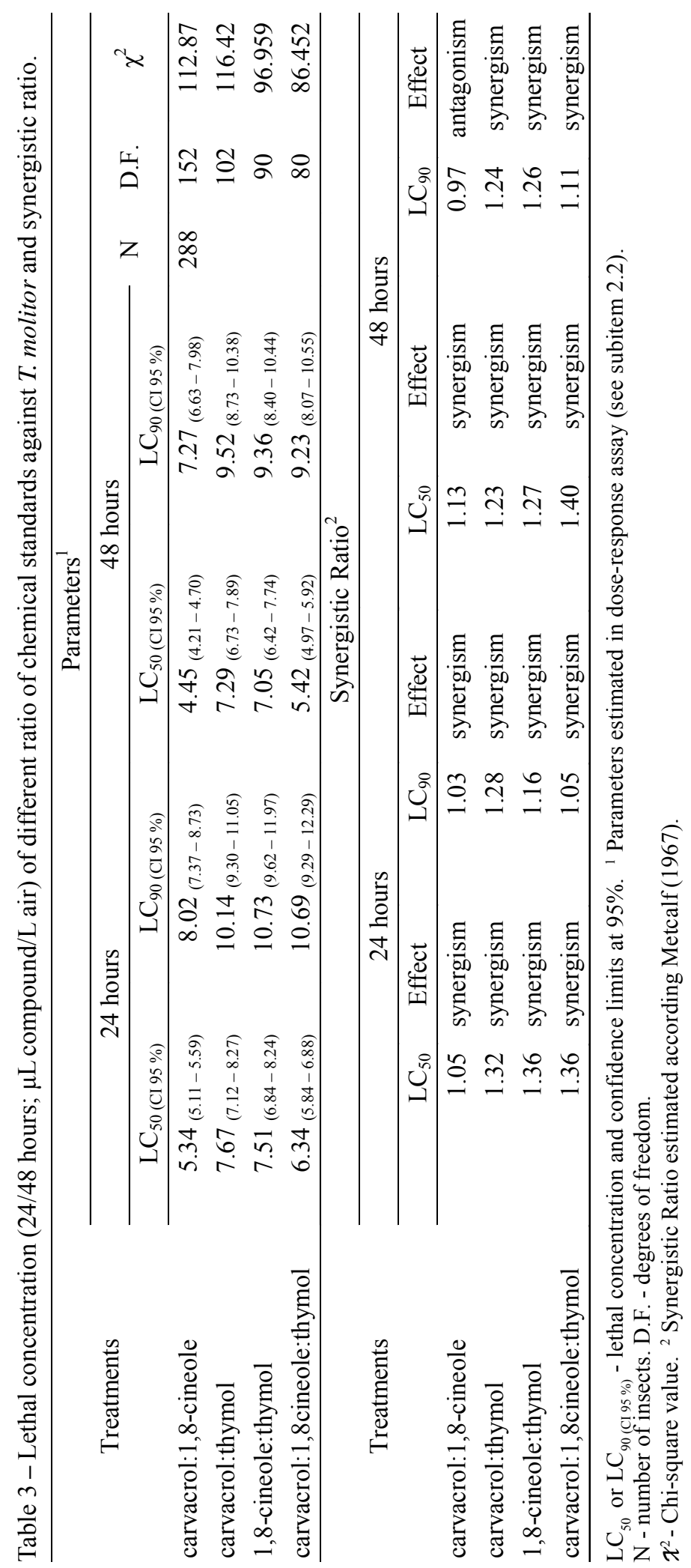

Ciênc. agrotec., Lavras, v. 35, n. 4, p. 664-671, jul./ago., 2011 
value of synergism were found when did a mixture of carvacrol:thymol (average of SR 1.27) and 1,8cineole:thymol (average of SR 1.26). With this result it can be suggested that thymol has a good role like synergist in mixture of carvacrol or 1,8-cineole (Table 3).

The synergism among monoterpenes is found in many essential oils and this effect was studied by Hummelbrunner and Isman (2001), who stood out that (E)-anetol acts synergistically with thymol, citronelal and $\alpha$-terpineol against the caterpillars Spodoptera litura (Fab.) (Lepidoptera:Noctuidae). As shown in this study, a large number of papers reports evidence the toxicity of essential oils against pests from stored products. Ho et al. (1994, 1996, 1997) demonstrated the toxicity of essential oils to insects, that have mainly cinnamic aldehyde, á-pinene, onethol, thymol and eugenol. According to Lee et al. (2003), the monoterpenes that may be volatiles and lipophylic, can penetrate through breathing and quickly intervene in physiological functions of insect. These compounds can also act directly as neurotoxic compounds, affecting acetylcholinesterase activity or octopamine receptors (ISMAN, 2000).

As this work, the inseticidal activity of $L$. sidoides was reported by Furtado et al. (2005) against A. aegypti, which was effective to kill the larvae. Botelho et al. (2007) found that essential oil of $L$. sidoides from Northeast Brazil has as major components thymol and carvacrol and Cavalcanti et al. (2004) also verified that this compound are toxic against $A$. aegypti larvae. Acording RegnaultRegnault-Roger and Hamraoui (1995), the monoterpenes carvacrol and thymol among others, have insecticidal activity against Acanthoscelides obtectus (Say.) (Coleoptera: Bruchidae), as well as them affect the reproduction of this coleopter. More recently, Choi et al. (2006) showed the toxicity of several monoterpenes against Lycoriella mali (Fitch) (Diptera: Sciaridae), as demonstrated in this research on carvacrol, 1,8-cineole and thymol had a good insecticidal activity.

The potential of essential oils can be shown not only in insects, but also in controlling mites. According Adamczyk et al. (2005), there are several thymol-based commercial insecticides to control Varroa destructor (Acari: Mesostigmata) in honeybee colony, as well as Novelino et al. (2007) found that this compound have toxic effect against the tick larvae Boophilus microplus (Canestrini) (Acari: Ixodidae), causing 100\% of mortality when applied at the ratio of $1 \%$ in DMSO. According to these authors, the efficiency of control is similar to that used in a synthetic mixture of clorfenvinfos+diclorvos. Although studies have demonstrated the power of essential oils against insect, Isman $(2000,2006)$ highlights that the toxicity of these compounds is directly linked to insect species, developmental phase and experimental conditions, requiring the achievement of a good experimental design to obtain satisfactory results.

\section{CONCLUSION}

In conclusion, the results showed that essential oil of $L$. sidoides presented as major constituents carvacrol, $\rho$-cymene, 1,8-cineole and $\gamma$-terpinene, being identified $92.53 \%$ of all constituents. By the toxicity assay, was verified that the essential oil of $L$. sidoides has insecticidal activity against $T$. molitor, as well as monoterpenes, carvacrol, 1,8-cineole and thymol. Moreover, these compounds may be used like a new tool in Integrated Pest Management. The synergistic effect of thymol can be used to increase the toxicity of carvacrol and 1,8-cineole, mainly in binary mixture as thymol:carvacrol or thymol:1,8-cineole.

\section{ACKNOWLEDGEMENTS}

We would like to thank the Laboratório de Análises e Sínteses de Agroquímicos, Departamento de Química, Universidade Federal de Viçosa; the Coordenação de Aperfeiçoamento de Pessoal de Nível Superior and Fundação de Amparo à Pesquisa do Estado de Minas Gerais to according the doctoral scholarship to the first author and other resources, as well as PhD. Priscila CintraSocolowski for the critical review.

\section{REFERENCES}

ADAMCZYK, S. et al. Evaluation of residues of essential oil components in honey after different antiVarroa treatments. Journal of Agricultural and Food Chemistry, Easton, v.53, n.26, p.10085-10090, 2005.

ADAMS, R.P. Identification of essential oil components by gas chromatography/mass spectroscopy. Ilinois: Allured, 2007. 804p.

BERTINI, L.M. et al. Perfil de sensibilidades de bactérias frente a óleos essenciais de algumas plantas do Nordeste do Brasil. Infarma, São Paulo, v.17, n.3, p.8083, 2005.

BOTELHO, M.A. et al. Antimicrobial activity of the essential oil from Lippia sidoides, carvacrol and thymol against oral pathogens. Brazilian Journal of Medicinal and Biological Research, São Paulo, v.40, n.3, p.349-356, 2007. 
CARTAXO, S.L.; SOUZA, M.M.A.; ALBUQUERQUE, U.P. Medicinal plants with bioprospecting potential used in semi-arid northeastern Brazil. Journal of

Ethnopharmacology, Lausanne, v.131, n.2, p.326-342, 2010.

CAVALCANTI, E.S.B. et al. Larvicidal activity of essential oils from Brazilian plants against Aedes aegypti L. Memórias do Instituto Oswaldo Cruz, Rio de Janeiro, v.99, n.5, p.541-544, 2004.

CAVALCANTI, S.C.H. et al. Composition and acaricidal activity of Lippia sidoides essential oil against two-spotted spider mite (Tetranychus urticae Koch). Bioresource Technology, Essex, v.101, n.2, p.829-832, 2010.

CHOI, W.S.et al. Fumigant toxicity of essential oils and monoterpenes against Lycoriella mali adults. Crop Protection, Guildford, v.25, n.4, p.398-401, 2006.

COSTA, S.M.O. et al. Constituintes químicos de Lippia sidoides (Cham.) Verbenaceae. Revista Brasileira de Farmacognosia, São Paulo, v.12, n.1, p.66-67, 2002. Suplemento.

FURTADO, R.F. et al. Larvicidal activity of essential oils against Aedes aegypti L. (Diptera: Culicidae). Neotropical Entomology, Londrina, v.34, n.5, p.843-847, 2005.

GARCIA, M. et al. Effects of some sesquiterpenes on the stored-product insect Tenebrio molitor (Coleoptera: Tenebrionidae). Revista de la Sociedad Entomológica Argentina, Buenos Aires, v.62, n.3/4, p.7-26, 2003.

GHINI, R.; SCHOENMAKER, I.A.S.; BETTIOL, W. Solarização do solo e incorporação de fontes de matéria orgânica no controle de Pythium spp. Pesquisa Agropecuária Brasileira, Brasília, v.37, n.9, p.1253-1261, 2002.

HO, S.H. et al. Potential of cloves (Syzygium aromaticum (L.) Merr. and Perry) as a grain protect against Tribolium castaneum (Herbst) and Sitophilus zeamais Motsch. Postharvest Biology and Technology, Amsterdam, v.4, n.1/2, p.179-183, 1994.

HO, S.H. et al. The oil of garlic, Allium sativum L. (Amaryllidaceae), as a potential grain protectant against T. castaneum (Herbst) and Sitophilus zeamais Motsch. Postharvest Biology and Technology, Amsterdam, v.9, n.1, p.41-48, 1996.
HO, S.H.; MA, Y.; HUANG, Y. Anethole, a potential insecticide from Illicium verum Hook F., against two stored product insects. International Pest Control, London, v.39, p.50-51, 1997.

HUMMELBRUNNER, L.A.; ISMAN, M.B. Acute, sublethal, antifeedant and synergistic effects of monoterpenoid essential oil compounds on the tobacco cutworm, Spodoptera litura (Lepidoptera, Noctuidae). Journal of Agricultural and Food Chemistry, Easton, v.49, n.2, p.715-720, 2001.

ISMAN, M.B. Botanical insecticides, deterrents, and repellents in modern agriculture and an increasingly regulated world. Annual Review of Entomology, Stanford, v. 51, p.45-66, 2006.

ISMAN, M.B. Plant essential oil for pest and disease management. Crop Protection, Guildford, v.19, n.8/10, p.603-608, 2000.

LEE, B.H. et al. Fumigant toxicity of essential oils from the Myrtaceae family and 1,8-cineole against 3 major stored-grain insects. Journal of Stored Products Research, Elmsford, v.40, n.5, p.553-564, 2004.

LEE, S.; PETERSON, C.J.; COATS, J.R. Fumigation toxicity of monoterpenoids to several stored product insects. Journal of Stored Products Research, Elmsford, v.39, n.1, p.77-85, 2003.

MATOS, F.J.A. Farmácias vivas: sistema de utilização de plantas medicinais projetado para pequenas comunidades. Fortaleza: UFC, 2002. 267p.

MENDES, S.S. et al. Evaluation of the analgesic and antiinflammatory effects of the essential oil Lippioa gracilis leaves. Journal of Ethnopharmacology, Lausanne, v.129, n.3, p.391-397, 2010.

METCALF, R.L. Mode of action of insecticide synergists. Annual Review of Entomology, Stanford, v.12, p.229-256, 1967.

NOVELINO, M.A.S.; DAEMON, E.; SOARES, G.L.G. Evaluation of the acaricide effect of thymol, menthol, salicylic acid, and methyl salicylate on Boophilus microplus (Canestrini, 1887) (Acari: Ixodidae) larvae. Parasitology Research, Berlin, v.101, n.3, p.809-811, 2007. 
OLIVEIRA, F.P. et al. Effectiveness of Lippia sidoides Cham. (Verbenaceae) essential oil in inhibiting the growth of Staphylococcus aureus strains isolated from clinical material. Revista Brasileira de Farmacognosia, São Paulo, v.16, n.4, p.510-516, 2006.

PINTO JUNIOR, A.R. Eficiência de terra de diatomáceas no controle de algumas pragas de milho armazenado a granel. Revista da Faculdade de Zootecnia, Veterinária e Agronomia de Uruguaiana, Uruguaiana, v.15, n.1, p.6170, 2008.

R DEVELOPMENT CORE TEAM. R: a language and environment for statistical computing. Viena: $\mathrm{R}$ Foundation for Statistical Computing, 2010. Disponível em: <ihttp://Www.R-project.org $>$. Acesso em: 20 out. 2010 .

REGNAULT-ROGER, C. The potential of botanical essential oils for insect pest control. Integrated Pest Management Reviews, London, v.2, n.1, p.25-34, 1997.
REGNAULT-ROGER, C.; HAMRAOUI, B. Fumigant toxic activity and reproductive inhibition induced by monoterpenes on Acanthoscelides obtectus (Say) (Coleoptera), a Bruchid of kidney bean (Phaseolus vulgaris L.). Journal of Stored Product Research, Cambridge, v.31, n.4, p.291-299, 1995.

RITZ, C.; STREIBIG, J.C. Bioassay analysis using R. Journal of Statistical Software, Los Angeles, v.12, n.5, p.1-22, 2005.

SAHAF, B.Z.; MOHARRAMIPOUR, S.; MESHKATALSADAT, M.H. Chemical constituents and fumigant toxicity of essential oil from Carum copticum against two stored product beetles. Insect Science, Wallingford, v.14, n.3, p.213-218, 2007.

SOUSA, E.M.B.D. et al. Experimental results for the extraction of essential oil from Lippia sidoides Cham. using pressurized carbon dioxide. Brazilian Journal of Chemical Engineering, São Paulo, v.19, n.2, p.229-241, 2002. 